\title{
DONOS DA FALA E A NARRATIVA UNIDIMENSIONAL NO MEIO RURAL: ANÁLISE DO DISCURSO SOBRE O PROJETO "PARANÁ 12 MESES"
}

\author{
João Carlos Dias de OLIVEIRA ${ }^{1}$ \\ Luiz Alexandre Gonçalves CUNHA ${ }^{2}$
}

RESUMO: Este artigo analisa notícias publicadas sobre o 'Paraná 12 Meses', projeto desenvolvido para pequenos produtores rurais, com a finalidade de compreender o problema do espaço ocupado pelos atores envolvidos, já que a proposta era de construção conjunta com as comunidades. Foi feita pesquisa qualitativa a partir da análise de discurso em jornais que abrangem as três regióes históricas do território paranaense. O objetivo foi verificar se a horizontalidade daí proveniente se consolidou em matérias e releases, através da identificação dos protagonistas da narrativa. $\mathrm{O}$ artigo verifica, ainda, a relação dos investimentos com o agronegócio, possivelmente apontado como caminho irreversível para a permanência do pequeno agricultor no meio rural. Tal estudo parte do conceito de unidimensionalidade marcusiana, que acusa o mundo moderno de tentar impor um caminho único para o desenvolvimento. A pesquisa demonstrou uma verticalização da narrativa com as vozes oficiais se apresentando em defesa do agronegócio transnacional.

PALAVRAS-CHAVE: Pequeno produtor. Paraná 12 Meses. Discurso neoliberal. Unidimensionalidade.

\footnotetext{
1 Centro de Ensino Superior dos Campos Gerais (Cescage), Ponta Grossa - PR - Brasil. Doutor em Ciências Sociais Aplicadas. Orcid: https://orcid.org/0000-0001-5551-3055. diasjcoliveira@gmail.com.

2 Universidade Estadual de Ponta Grossa (UEPG), Ponta Grossa - PR - Brasil. Professor associado. Doutor em Ciências Sociais em Desenvolvimento, Agricultura e Sociedade. Orcid: https://orcid.org/0000-0001-8830-6060. ccunhageo@uepg.br.
} 
Donos da fala e a narrativa unidimensional no meio rural:

análise do discurso sobre o projeto "Paraná 12 Meses"

\title{
OWNERS OF SPEECH AND THE UNIDIMENSIONAL NARRATIVE IN THE RURAL ENVIRONMENT: DISCOURSE ANALYSIS ABOUT THE PROJECT "PARANÁ 12 MESES"
}

\begin{abstract}
This article analyzes published news about 'Paraná 12 Meses', a project developed for small rural producers, with the purpose of understanding the problem of the space occupied by the actors involved, since the proposal was for joint construction with the communities. Qualitative research was carried out based on discourse analysis in newspapers that cover the three historical regions of the territory of Parana. The objective was to verify whether the horizontality that came from it was consolidated in articles and releases, through the identification of the protagonists of the narrative. The article also verifies the relationship between investments and agribusiness, possibly pointed out as an irreversible way for small farmers to remain in rural areas. This study is based on the concept of Marcusian one-dimensional, which accuses the modern world of trying to impose a unique path for development. The research demonstrated a verticalization of the narrative with the official voices presenting themselves in defense of transnational agribusiness.
\end{abstract}

KEYWORDS: Small producer. Paraná 12 Meses. Neoliberal discourse. One-dimensionality.

\section{Introdução}

No final da década de 1990, num contexto de domínio neoliberal no Brasil e, paradoxalmente, fortalecimento dos movimentos sociais, foi lançado pelo governo do Estado do Paraná o 'Projeto Paraná $12 \mathrm{Meses}^{\text {'3 }}$, que tinha como proposta apoiar financeiramente iniciativas voltadas para o pequeno produtor rural, ou agricultor familiar, de acordo com o conceito do agronegócio adotado pelo governo. Havia a necessidade de investir no setor, que tinha sido intensamente afetado pelas políticas públicas das décadas de 1960 e 1970, e geraram empobrecimento e êxodo rural dos pequenos produtores devido aos efeitos da "revolução verde", que tecnificou o campo, priorizando a produção de grãos em larga escala, o que podia ser bancado, com financiamento público, basicamente por grandes produtores.

'O Projeto Paraná 12 Meses' foi executado pelo governo Jaime Lerner em parceria com o Banco Mundial (BIRD), que defendia as causas neoliberais e exigia posição igual dos países em desenvolvimento, conforme Pereira (2017a).

3 O nome do projeto faz uma referência à ideia de funcionar durante todos os meses do ano. 
Como o governo do Estado adotava a mesma ideologia do banco, o discurso estava mais afinado, o que facilitou a liberação do empréstimo. A proposta era de desenvolver açóes para fortalecer o pequeno estabelecimento rural, tornando-o eficiente, competitivo e lucrativo, além de melhorar habitaçóes e saneamento básico. Para isso, foi fechado acordo de investimento de 353,5 milhóes de dólares, com 50\% financiados pelo Banco Mundial (PARANÁ, 1997).

Houve participação de pelo menos oito secretarias, com destaque para a Secretaria de Estado da Agricultura e do Abastecimento (SEAB), junto com suas subsidiárias: Emater-PR $\mathrm{PR}^{4}$, Iapar ${ }^{5}$ e Codapar ${ }^{6}$. "Todos os trabalhos envolveram os profissionais de assistência técnica para a implantação das propostas" (PARANÁ, 1997 , p. 20). Além dessa estrutura, havia uma proposta de decisão em conjunto de onde e como aplicar os recursos a partir de comissóes regionais e conselhos municipais, que envolviam órgãos governamentais, representantes de prefeituras, ONGs, sindicatos rurais e beneficiários. Nas comunidades rurais, envolvia microbacias ou vilas rurais, com grupos formalizados de beneficiários (IPARDES, 2006). As atividades seriam executadas por instituiçóes públicas e privadas.

O problema pesquisado parte da indagação sobre os documentos oficiais, que diziam que os beneficiários teriam um papel efetivo no desenvolvimento das propostas, que seriam, assim, concretizadas em conjunto, com o pequeno produtor sendo o protagonista principal e não apenas objeto de açôes (PARANÁ, 1997). A participação dos pequenos produtores ocorreria em todas as etapas de execuçáo, eram eles que iam decidir onde e como o dinheiro seria utilizado, claro que obedecendo aos projetos técnicos desenvolvidos pela equipe de extensionistas, composta principalmente, pela assistência técnica do Estado.

Assim, o objetivo geral deste artigo é utilizar a análise de discurso para verificar se a construção conjunta propagada aconteceu na prática narrativa. A posição dos atores e suas falas podem ser um indicativo de igualdade ou não na tomada de decisóes e desenvolvimento do pequeno estabelecimento rural a partir do 'Paraná 12 Meses'. A paridade deveria ocorrer diante de um grupo que contava com governo, técnicos e até iniciativa privada. A hipótese é de que o protagonismo do público beneficiário não transparece no discurso levado a público, que na verdade recaiu principalmente para governo e políticos. Diante disso, os objetivos específicos pretendem mostrar quais são os atores em destaque na fala; o que dizem sobre o 'Paraná 12 Meses'; de que posição o sujeito protagonista

\footnotetext{
4 Empresa Paranaense de Assistência Técnica e Extensão Rural.

5 Instituto Agronômico do Paraná.

6 Companhia Paranaense de Desenvolvimento Agropecuário.
} 
fala, dentro do cenário estabelecido; e que papel coube, enquanto emissor, ao pequeno produtor e ao trabalhador rural.

A justificativa para o desenvolvimento do artigo é levantar o debate sobre o fato de que muitas vezes governos podem desenvolver políticas públicas de posicionamento unidimensional (MARCUSE, 1969, 1973, 1975, 1998) em favor do sistema produtivo do modelo agroindustrial e, ao mesmo tempo, se apropriar de discursos inclusivos e horizontais, sem que isso se confirme na prática. A partir de um estudo de caso do 'Paraná 12 Meses', projeto desenvolvido antes da popularização da internet, pode ser possível verificar que mesmo as políticas voltadas para, pretensamente, resgatar o campesinato, estão sujeitas a uma narrativa real de modelo único. Nesse caso analisado, a propagação discursiva se valia dos principais veículos de comunicação, especialmente os impressos.

O 'Paraná 12 Meses' teve início em 1998, no segundo mandato do governador Jaime Lerner (PFL), aliado político do governo Fernando Henrique Cardoso. Até por isso, defendia as mesmas ideias neoliberais, do estado mínimo e de privatização de empresas e serviços. $\mathrm{O}$ projeto continuou no governo seguinte, mas o recorte deste trabalho foi fechado em 2002, com o fim do período Lerner. Até porque, o governo seguinte, de Roberto Requião (PMDB) era antagônico ao discurso neoliberal "lernista", propagado ainda que os personagens políticos envolvidos tivessem um perfil muito mais patrimonialista do que liberal.

\section{Formação rural e agrária paranaense}

Para compreender melhor quem é o ator em questão, alvo do 'Projeto Paraná 12 Meses', é importante destacar suas origens, que não são únicas, uma vez que o Estado passou por três grandes frentes de ocupação em diferentes períodos, que originaram pequenos estabelecimentos e produtores rurais. A partir do século XVII começou a ocupação do chamado 'Paraná Tradicional', que povoou do litoral até as áreas de campo. Só mais tarde, entre os séculos XIX e XX, foram colonizadas as regióes Norte e Sudoeste, processo concluído apenas na década de 1960. Nesse contexto foi construído o espaço rural e surgiu o camponês, ou agricultor familiar.

Garimpeiros paulistas chegaram ao litoral paranaense no final do século XVI, em busca de ouro de aluvião (PADIZ, 2006). A atividade ajudou a desenvolver vilas e pequenos roçados de subsistência. Com o fim da aventura garimpeira e a descoberta do metal precioso no Planalto Central do País, muitos partiram para Minas Gerais, Goiás e Mato Grosso. Aqueles que ficaram subiram a serra até os campos de Curitiba onde tiveram pouco sucesso na mineração 
(MACHADO, 1962), que foi então substituída por outras atividades econômicas, como a pecuária extensiva, tropeirismo, extração da erva-mate e de madeira (SERRA, 1992). Toda a região formava o chamado 'Paraná Tradicional'.

A atividade historicamente mais marcante no processo de ocupação dos campos paranaenses foi o tropeirismo que, a partir do início do ciclo do ouro, em Minas Gerais e Planalto Central do Brasil, teve impacto na região graças à localização, já que o futuro Estado do Paraná estava no caminho das tropas vindas do Sul (PADIZ, 2006). Os tropeiros levavam muares do Rio Grande do Sul para a grande feira de Sorocaba-SP, atravessando os planaltos paranaenses, o que movimentava a economia local e fazia surgir vilas no caminho.

Nesse território, composto principalmente de grandes sesmarias, vivia não apenas o fazendeiro, mas também o caboclo, o agregado e o ex-escravo, que formaram a primeira geração de pequenos produtores rurais do Estado. Machado (1962) explica que essa gente estava sujeita ao sistema de mandonismo local. Em geral, a população pobre se ocupava principalmente das terras aparentemente sem dono, onde construíam pequenas casas e ali viviam até que algum proprietário de sesmaria requisitasse a posse (SERRA, 1992).

A partir do século XIX começaram a chegar imigrantes europeus ao Paraná. Eles se somaram aos que aqui já viviam como formadores do universo camponês local. A chegada de estrangeiros se deu a partir de políticas migratórias criadas para ocupar as terras e tentar resolver o desabastecimento de alimentos, comum na época (MACHADO, 1962).

\section{Ocupação da fronteira norte}

A Regiāo Norte, composta de matas fechadas, começou a ser ocupada no século XIX pelo Norte Pioneiro, mas de forma insipiente. O grande crescimento regional se deu no século XX (PADIZ, 2006), quando projetos de colonização foram instalados, atraindo milhares de famílias dispostas a adquirir um pedaço de terra roxa para o cultivo agrícola. A forma de colonização capitalista fez surgir um tipo de pequeno produtor no Norte do Estado diferente do camponês do Paraná Tradicional, já que além da subsistência, ele produzia café, principal cultura do país na primeira metade do século passado.

A cafeicultura avançou do Norte para o Noroeste, no que é considerado o maior investimento imobiliário privado já visto (FAJARDO, 2007). Segundo o autor, o baixo preço da terra e facilidades para pagar atraíram colonos de São Paulo, Minas Gerais e do Nordeste. O auge desse movimento aconteceu entre as décadas de 1930 e 1950. 


\section{Colonização do Sudoeste}

A última região do Paraná a ser alvo de projetos de colonização foi a Sudoeste. Até os anos 1940 não havia uma grande procura por aquelas terras. Segundo Padiz (2006), tinha ocorrido apenas um movimento ligado à economia madeireira, estruturada por grandes propriedades, já que o objetivo era a posse e derrubada das reservas de pinhais. Uma pecuária extensiva acontecia de forma complementar nos campos da região.

$\mathrm{Na}$ década de 1940 começaram a chegar agricultores catarinenses e gaúchos, somando-se à expansão das lavouras de café, vindas do Norte, o que Padiz (2006) considera como o segundo movimento de colonização do Sudoeste. Os pequenos agricultores gaúchos e catarinenses sofriam com o problema do minifúndio gerado por divisão das poucas terras entre herdeiros. Para eles, terras em abundância e a preços aceitáveis faziam com que muitos migrassem em busca dessas áreas (PADIZ, 2006). Os novos camponeses deram uma configuraçáo diferente para a regiáo, que passou a contar com maior número de pequenos estabelecimentos (FAJARDO, 2007).

A história da ocupação demonstra que o surgimento do pequeno produtor rural aconteceu sem uma transformação na estrutura fundiária paranaense. Os novos colonos, estrangeiros e nacionais passaram a conviver com o latifúndio tradicional e com novos grandes proprietários que também se instalaram nas fronteiras do Norte e Sudoeste.

\section{Revolução verde e crise camponesa}

A partir da década de 1960 o meio rural paranaense experimentou mais uma transformação, com a inserção das novas tecnologias da chamada "modernização" da agricultura, ou "revolução verde". Nesse período, as áreas agrícolas começaram a integrar tais tecnologias, com o uso de insumos, defensivos químicos e mecanização, voltados principalmente para o cultivo de produtos agrícolas pré-definidos, de interesse da agroindústria. As unidades produtivas autossuficientes em quase todas as necessidades foram trocadas por um modelo totalmente atrelado ao que queriam os industriais.

A "revolução verde" iniciou pelo Norte do Paraná. Depois se estendeu para as outras regióes, de acordo com as condiçóes de adaptação tecnológica (CUNHA, 2015). O capital financeiro, articulado com a produção agroindustrial, passou a beneficiar os grandes produtores, que tinham condiçóes de obter crédito rural dos programas de governo. $\mathrm{O}$ interesse oficial em apoiar a produção 
de soja no País encontrou boas condições no Norte do Paraná, onde a cafeicultura estava em crise (PADIZ, 2006). Além da olericultura, trigo e milho passaram a ocupar áreas onde os cafezais foram erradicados (ROLIM, 1995). As lavouras tecnificadas, em substituição ao café, que ocupava mais mão de obra, gerou 290 mil desempregados no campo (SERRA, 2015).

\section{Concentração fundiária e êxodo rural}

A concentração fundiária aumentou em todo Estado, principalmente no Norte, a partir da década de 1960. Foram criadas políticas públicas para incentivar a sojicultura com créditos generosos, o que fez aumentar muito a produção da oleaginosa na década de 1970, elevando junto o cultivo de trigo. Serra (2015) diz que alguns pequenos produtores decidiram tentar a mecanização e produção de soja, mas a maioria não deu conta de pagar as dívidas e acabou perdendo a propriedade, que já era pequena.

De acordo com relatório do Codesul ${ }^{7}$, publicado em 1978, entre as décadas de 1960 e 1970 houve um incremento sensível no número de estabelecimentos rurais no Paraná, ainda resultante dos processos recentes de colonização do Oeste/Sudoeste e Norte do Estado. Já a partir da década de 1970 foi registrada redução de mais de 100 mil estabelecimentos, todos de pequenos produtores rurais. O período em questão coincide com a consolidação da chamada revolução verde e da agroindustrialização paranaense, que vai até o final da década de 1980. Na época, foi registrado um crescimento constante de grandes propriedades (acima de 100 hectares), segundo o relatório. Em termos de área, entre as décadas de 1960 e 1970 desapareceram 24,2\% dos estabelecimentos com menos de 20 hectares, enquanto grandes fazendas, com mais de 500 hectares tiveram incremento de 43,8\% (CODESUL, 1978).

Tabela 1 - Área dos estabelecimentos rurais do

Paraná entre as décadas de 1960 e 1980

\begin{tabular}{|l|c|c|c|c|}
\hline ESTABELECIMENTOS & 1960 & 1970 & 1975 & 1980 \\
\hline Até 50 ha & 3.727 .421 ha & 6.111 .565 ha & 5.468 .288 ha & 5.217 .961 ha \\
\hline De 50 a 100 ha & 1.537 .852 há & 1.560 .825 ha & 1.673 .543 ha & 1.758 .795 ha \\
\hline Mais de 100 ha & 6.119 .661 ha & 6.953 .139 ha & 8.636 .905 ha & 9.403 .570 ha \\
\hline
\end{tabular}

Fonte: Relatório Codesul (1978).

Conselho de Desenvolvimento e Integração Sul. 
A própria extensão rural do Estado $^{8}$, de acordo com Sepulcri (2005), na época, deu prioridade aos agricultores com maior capacidade de inserção ao modelo de produção de grãos de forma mecanizada, ou seja, os mais capitalizados. O crédito rural era a principal alavanca de recursos para a extensão rural difundir pacotes tecnológicos das multinacionais do setor (SEPULCRI, 2005). Isso mostra que o governo estava completamente alinhado aos interesses da agroindústria.

A tabela 1 mostra o movimento de redução de pequenos estabelecimentos e o crescimento das grandes e médias propriedades no período de 1970 a 1980, o que comprova a forte concentração da terra que se observava no Paraná (SILVA, 1996). O resultado foi o êxodo rural e aquisição de terras por grandes produtores de gráos ou pecuaristas.

Em 10 anos, o meio rural paranaense perdeu 1.268.565 habitantes (FERREIRA, 1987). Ao chegar à década de 1980, a "modernização" da agricultura estava consolidada no Paraná. Por outro lado, o processo de exclusão causou danos sociais que aprofundaram as distâncias entre grandes e pequenos produtores. Balsan (2006) diz que os agricultores que permaneceram no campo foram subordinados às cadeias especializadas, desde latifundiários até pequenos produtores familiares. O homem do campo foi confrontado com o próprio trabalho, que passou a ser reificado, independente dele, como diz Lukács (2003).

\section{Políticas públicas para a pequena propriedade}

O quadro resultante do processo anterior influenciou as políticas públicas posteriores para a agricultura familiar. Os pequenos produtores foram, portanto, impactados diretamente pela chamada 'modernizaçáo', que tecnificou propriedades - principalmente grandes fazendas - e levou à ruína e ao êxodo rural muitas famílias que não conseguiram acompanhar as mudanças do agronegócio, consolidado nos anos seguintes. Anos depois, programas e projetos como o 'Paraná 12 Meses' surgiram, não para restabelecer o espaço da pequena produção ou fazer uma reforma fundiária, mas para inserir na mesma proposta os pequenos agricultores que continuavam no campo, transformados conceitualmente em 'agricultores familiares'.

\footnotetext{
8 A extensão rural e assistência técnica aos agricultores, no Paraná, iniciou em 1956 com a instalação do Escritório Técnico de Agricultura (ETA) que foi substituído pela Associação de Crédito e Assistência Rural do Paraná (Acarpa) em 1959. Posteriormente, em 1978, a Acarpa foi substituída pela Empresa Paranaense de Assistência Técnica e Extensão Rural (Emater-PR) (SEPULCRI, 2005), hoje, transformado em instituto, mas com a mesma sigla.
} 
A partir do final dos anos 1970, os governos paranaenses começaram a desenvolver políticas públicas para recuperação do pequeno estabelecimento rural. O primeiro foi o 'Programa de Apoio ao Pequeno Produtor' (PAPP), que serviu de base para o 'Projeto Integrado de Apoio ao Pequeno Produtor Rural' (Pro-Rural), iniciado em 1981 e financiado pelo Banco Interamericano de Desenvolvimento (BID), segundo Sepulcri (2005). Na sequência, em 1984, foi implantado o 'Programa de Manejo Integrado de Solos e Água' (PMISA), voltado para microbacias hidrográficas (PARANÁ, 1997). Em 1989 foi lançado o 'Projeto Paraná Rural', que aplicou 148 milhôes de dólares do BID e do Banco Internacional de Reconstrução e Desenvolvimento (BIRD). O objetivo era resolver problemas ocasionados pela mecanização agrícola, especialmente a erosão e degradação do solo (BANCO MUNDIAL, 1997).

O 'Paraná Rural' durou até 1997, quando foi substituído pelo 'Paraná 12 Meses', projeto foco deste estudo. $\mathrm{O}$ destaque central era o combate à pobreza no meio rural, com açóes que fortalecessem o pequeno estabelecimento rural dentro de conceitos neoliberais, como eficiência, competitividade e lucratividade.

\section{O Banco Mundial e propostas neoliberais}

Em 1995, executivos do Banco Mundial (BIRD) procuraram a Secretaria de Estado do Planejamento com o objetivo de propor um projeto para o meio rural (IPARDES, 2006). Nesse período a instituição financeira atuava alinhada às causas neoliberais e, assim, exigia ditames do mercado e ajustes estruturais às condiçôes da economia e política de tal pensamento (PEREIRA, 2017a). O banco propunha controle da inflação e estabilização a partir de medidas como redução do consumo interno, abertura do comércio e privatização de empresas públicas (PEREIRA, 2017b).

Foi dentro desse contexto que o Banco Mundial voltou a dar crédito para projetos e programas agrários, segundo Pereira (2017b). Na visão da direçáo do BIRD, com o fim da Guerra Fria, a questão fundiária já podia ser tratada sem ideologia (PEREIRA, 2017b), o que significava a manutenção das estruturas como estavam e, assim, dar segurança para o chamado setor produtivo, com regras que beneficiassem o capital. Dessa forma é que a aplicação dos recursos era submetida aos interesses do agronegócio.

O público a ser atendido, de acordo com a proposta, era do produtor familiar, em que a família fosse a responsável principal pelas atividades diárias da produção. O conceito da unidade familiar abrangia as categorias de 'Produtor de Subsistência', 'Produtor Simples de Mercadorias' e 'Empresário Familiar'. 
Os projetos deveriam ser desenvolvidos a partir de demandas elaboradas no município, via escritório local da Emater. Isso depois que o Conselho Municipal definisse os itens a serem apoiados (PARANÁ, 1997).

\section{Conceito de agricultura familiar}

Ainda que não apareça de forma totalmente clara no discurso, a coordenação do 'Projeto' optou pelo conceito de agricultura familiar na narrativa do 'Paraná 12 Meses'. O uso de camponês ou agricultor familiar depende da posição ideológica de quem o adota. Altafin (2005) lembra que os movimentos sociais adotam o termo 'camponês' em oposição ao latifúndio, denominação usada para se referir à grande propriedade. Entre o final dos anos 1970 e início dos anos 1980, segundo a autora, o setor do agronegócio passou a usar de forma mais consistente o termo "agricultura familiar" para se opor à ideia de campesinato dos movimentos sociais, por isso o termo teria se tornado ideológico. Nos clássicos escritos de José de Souza Martins (1986) essas são expressôes políticas, já que definem posicionamento frente às formas de produção capitalistas.

Wilkson (2000) também atribui ao setor agroindustrial as distinçóes entre os dois conceitos. Assim, a discussão se tornou cada vez mais política, com base em maior integração ou exclusão ao modelo capitalista. Fernandes (2004) nota que quem adota o conceito de 'agricultura familiar' náo usa o termo camponês. Para o autor, a integração ao agronegócio, incentivado por políticas públicas, levou à adoção, por parte de muitos pequenos produtores, de tecnologias modernas e atrelamento ao mercado agroindustrial.

Os governos adotaram também definições normativas sobre o tema. No Paraná, na década de 1990, a Secretaria de Estado da Agricultura e do Abastecimento (SEAB) considerava agricultor familiar aquele com área inferior a 50 hectares e renda, prioritariamente, das atividades econômicas vinculadas à terra, com a mão de obra sendo essencialmente da família (PARANÁ, 1996).

\section{Público do Projeto Paraná 12 Meses}

Com os pequenos produtores já conceitualmente definidos como agricultores familiares, as divisôes seguiram mesmo os critérios técnicos. Os beneficiários foram divididos em categorias específicas. Assim, para efeito do projeto, foram classificados em 'Produtores de Subsistência' (PS), 'Produtores Simples de Mercadorias' (PSM), 'Empresário Familiar' (EF) e 'Empresário Rural' (ER). Os PSM foram subdivididos de acordo com tamanho do estabelecimento e capital 
em três diferentes faixas, com área de até 50 hectares e percentual de mão de obra familiar variando de $50 \%$ a $80 \%$.

De acordo com o projeto, 'produtores de subsistência' são aqueles com a produção voltada preferencialmente para o consumo e venda apenas do excedente. Nesse caso, uma parte da renda pode vir do trabalho fora do estabelecimento. A diferença para o chamado 'produtor simples de mercadorias', é que este tem pelo menos um produto cultivado para o mercado. Ambos devem usar prioritariamente mão de obra familiar. O 'empresário familiar' trabalha voltado para o mercado, com forte participação da mão de obra própria, mas também podendo usar, em alguns momentos, trabalho contratado. Já o 'empresário rural' atua exclusivamente para o agronegócio, com empregados. Candidatos a beneficiários precisavam se enquadrar nos critérios definidos de área, renda, estrutura e ocupação. O público a ser atendido incluía todos os produtores rurais, de forma indireta, mas apenas os 'Produtores de Subsistência' e 'Produtores Simples de Mercadoria' contariam com financiamento. Outra categoria era dos 'trabalhadores rurais volantes', atendidos através do 'Programa Vilas Rurais9', iniciado em 1995 e que passou a compor o 'Paraná 12 Meses’ em 1997.

O documento síntese do projeto trazia como proposta, a participação dos beneficiários nas discussóes de forma horizontal, sendo assim, protagonistas principais no desenvolvimento e não objetos passivos do que chamavam de açóes paternalistas/assistencialistas. A opção por um modelo neoliberal se destacava no documento, quando dizia que o objetivo era

[...] apoiar mecanismos de aumento de ingressos de renda na unidade produtiva, aqueles que propiciam maior capacidade de competição frente a abertura de mercado e a redução da participação do Estado no processo econômico. (PARANÁ, 1997, p. 14).

A justificativa de cunho neoliberal criticava os programas rurais anteriores, que teriam sido marcados por protecionismo intenso e elevados investimentos públicos. Isso teria criado, na visão do 'Projeto', um cenário econômico artificial que levou à redução de crédito de longo prazo, aumento da inflação e marginalização de boa parte da população, segundo a visão do governo (PARANÁ, 1997).

\footnotetext{
9 O Programa Vilas Rurais, criado 2 anos antes, financiava núcleos rurais com áreas de 5 mil metros quadrados com casas de 40 metros quadrados para trabalhadores rurais. O objetivo era oferecer moradia e possibilidade de produção para o consumo e venda do excedente. O programa causou controvérsia por ser apresentado como "reforma agrária sem violência", muitas vezes, pelo governo, políticos de direita e agropecuaristas. O conceito não cabia porque as áreas eram muito inferiores à uma pequena propriedade rural.
} 


\section{Metodologia de pesquisa}

A pesquisa foi realizada a partir de notícias sobre o projeto publicadas, na época, em jornais. Foram levantados matérias e releases do governo do Estado veiculados por três veículos de comunicação que representam as divisôes histórico/geográficas do Paraná: o Paraná Tradicional, Norte e Sudoeste/Oeste. Assim, foram pesquisadas ediçóes do 'Diário da Manhã' (Ponta Grossa-Paraná Tradicional), 'Folha de Londrina' (Londrina-Norte) e 'O Paraná' (CascavelSudoeste/Oeste). O objetivo foi obter uma análise que envolvesse o Estado da forma mais abrangente possível. Foram pesquisadas quase 4 mil ediçóes e encontrados 326 textos, entre releases, matérias feitas por equipes dos próprios veículos e artigos.

Os três jornais analisados eram empresas privadas, com um proprietário específico. A 'Folha de Londrina', à época, pertencia ao banqueiro José Eduardo de Andrade Vieira, que fora ministro dos governos Itamar Franco e Fernando Henrique Cardoso. Ele era filiado ao PTB, partido de situação ao governo Lerner. Já o 'Diário da Manhâ' (extinto) pertencia ao jornalista provisionado Adail Inglês, que também era militante de direita na política local. Por fim, 'O Paraná, pertencia a André Costi, que tinha apenas negócios em comunicação. O jornal se diz, ainda hoje, "grande defensor das causas do Oeste do Paraná". Tal aspecto empresarial/capitalista aponta para uma relação de simpatia dos proprietários de tais negócios com o governo que se dizia neoliberal e era privatista.

De acordo com a pesquisa realizada, percebe-se que as matérias tiveram como origem três fontes principais: prefeitura, governo do Estado, núcleos regionais e municipais de secretarias estaduais e empresas públicas. Com os releases não foi muito diferente: alguns partiram de assessorias dos núcleos e escritórios regionais dos órgãos públicos estaduais e prefeituras, mas a maioria saiu da Agência Estadual de Notícias (AEN).

A AEN é um órgão oficial do governo do Estado do Paraná e pode ser acessada no endereço http://www.aen.pr.gov.br/. A reprodução pode ser feita em partes ou integralmente, sem custos. A utilização de tal material já denota uma clara parcialidade da informação pendendo para a narrativa governamental. Fanini, Souza e Pereira (2015) dizem, em relação ao fluxo da notícia a partir da $\mathrm{AEN}$, que há um firme controle da informação, apresentado pelos governantes e os veículos de comunicação publicam o que é de interesse dos governos em troca de cotas publicitárias. 


\section{Análise da objetividade e imparcialidade}

As avaliações sobre fontes de matérias jornalísticas e releases já apresentam um indicativo sobre o lado para o qual pende a narrativa do Projeto Paraná 12 Meses. Segundo Duarte (2012), as empresas de comunicação têm seus próprios critérios de veiculação, muitas vezes comprometidos com determinados interesses, o que pode ter ocorrido com os três veículos estudados.

Além do atrelamento natural ao discurso governamental, as fontes estão relacionadas ao que Traquina (2012) chama de "rotinização", que faz com que os jornalistas recorram a poucas fontes de informação e desenvolvam certo relacionamento com elas, o que traz facilidade para o profissional e publicização para as fontes, principalmente as oficiais. Mafei (2012) considera que inexperiência, pressa ou necessidade de dar maior destaque ao fato levam a uma falsa objetividade ou imparcialidade.

$\mathrm{O}$ agendamento, como o percebido a partir das fontes das matérias e dos releases, projetam os atores e assuntos. $\mathrm{O}$ reconhecimento do que acontece no mundo real se dá pela divulgação dos fatos e daí se projeta consenso ou negação de propostas (CAMILOTTO; CRHISPIN; LOPES FILHO, 2015). Tais posiçôes colocam em xeque a imparcialidade e objetividade jornalística, que não é totalmente possível ou mesmo desejável, segundo Barros Filho (2003), para quem a objetividade se apresenta impossível porque ao observador (entrevistado ou narrador) cabem limitaçôes, história e preferências. Ao jornalismo também se opóem espaço, tempo e escolha das fontes.

\section{Pesquisa documental}

Para a compreensão do 'Projeto', foram pesquisados, também, os documentos do 'Paraná 12 Meses': 'Projeto Paraná 12 Meses - Síntese' (PARANÁ, 1997); Site da Secretaria de Estado da Agricultura e do Abastecimento (SEAB) ${ }^{10}$ e Manual de Campo (PARANÁ, 1996). Os documentos foram trabalhados a partir da análise qualitativa dos elementos discursivos presentes nos textos. Para destacar os conceitos elaborados, foram feitos levantamentos quantitativos, mas apenas para dimensionar a importância e relevância do aspecto estudado dentro do discurso. Toda análise foi feita manualmente, tendo como elementos chaves, palavras, frases, ideias e lugar de fala dos personagens.

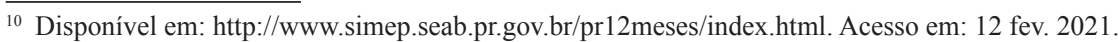


Realizou-se análise de discurso dos materiais partir dos conceitos de Carvalho (2013), Charaudeau (2010, 2016), Pêcheux (2006) e Orlandi (2007, 2008), esta última, autora que diz que a análise de discurso deve se valer da palavra em movimento e de saber como o texto significa. Por isso interessa a observação de como os atores aparecem no cenário (SOUZA, 1984) das matérias e releases, se sujeitos ou objetos da ação e, assim, refletir sobre a horizontalidade proposta no 'Projeto Paraná 12 Meses'.

A análise de discurso se apresenta como uma tentativa semiológica de interpretar a sociedade a partir dos processos de comunicação (CARVALHO, 2013). Para Pêcheux (2006), a pesquisa deve questionar a existência do real, já que sempre há outro conhecimento ou intensão diferentes do que foi exposto. Charaudeau (2016) destaca que a partir do século XX, governos e mídia passaram a usar a propaganda para instrumentalizar a sociedade civil. Os releases funcionam como porta-vozes das mensagens oficiais. Dessa forma, os meios de comunicação fornecem espaço para a análise do discurso revelar elementos não explícitos (CARVALHO, 2013). O autor lembra que o texto jornalístico é apresentado como sendo objetivo, mas esconde posiçóes e ideologias.

Orlandi (2007) explica que a análise de discurso apresenta a linguagem como mediadora entre o homem, a realidade e a sociedade. Com isso, a posição imaginária ganha relevância. Por exemplo, não é o agricultor real que o receptor vai conhecer, mas aquele imaginado a partir de determinada posição ideológica produzida pelo emissor.

Constitui nesse confronto do simbólico com o político e processos que ligam discursos e instituiçôes. Desse modo é que acreditamos que o sujeito na posição do professor de esquerda fale $\mathrm{X}$ enquanto um de direita fale $\mathrm{Y}$. (...) Os sentidos não estão nas palavras, nelas mesmas, estão aquém e além delas. (ORLANDI, 2007, p.42).

O emissor atua dentro de uma conjuntura, com posiçóes determinadas conforme a posição de onde se enuncia e de onde se recebe a mensagem. A ideologia pode, entâo, ser compreendida como um instrumento de dominaçáo. Charaudeau (2016) observa que a presença de autoridades na produção do discurso legitima conceitos e propostas. 


\section{Análise do discurso e os atores centrais}

Durante os quatro anos do 'Paraná 12 Meses' dentro do governo Jaime Lerner, o projeto teve espaço nos jornais do Estado via publicação de releases, matérias produzidas pelos veículos e artigos. Das mais de 4 mil ediçóes pesquisadas do 'Diário da Manhã', 'Folha de Londrina' e 'O Paraná' foram então selecionados os 326 textos para análise, divididos conforme a tabela 2.

Tabela 2 - Publicaçóes sobre o Paraná 12 Meses publicados de 1998 a 2002

\begin{tabular}{l|c|c|c}
\hline & Releases/ Artigos & Matérias do jornal & Publicações \\
\hline Diário da Manhã & 99 & 62 & 161 \\
\hline Folha de Londrina & 12 & 35 & 48 \\
\hline O Paraná & 83 & 34 & 117 \\
\hline TOTAL & 189 & 133 & 326 \\
\hline
\end{tabular}

Fonte: Elaboração própria com base na análise dos jornais consultados na pesquisa.

Para efeito deste artigo, foram verificadas discursividades sobre o projeto neoliberal que mostrariam se havia defesa do estado mínimo e aumento da participação da iniciativa privada, defesa do capital, da globalização, do agronegócio, e do mercado, o que demonstraria a unidimensionalidade da proposta. Além disso, buscou-se identificar os atores protagonistas, o que diziam sobre o 'Paraná 12 Meses', em que cenário e de que posição o sujeito falava. Também foi analisado qual era o papel do pequeno produtor enquanto emissor.

\section{A narrativa da construção conjunta}

Havia uma afirmação recorrente da construção do projeto com a participação do pequeno produtor, como pode ser visto no quadro 1 . A ideia de que a elaboraçáo das propostas seria em conjunto com as comunidades esteve presente em diversas matérias que reafirmaram a participação direta do beneficiário. Mas vale ressaltar que o assunto sempre partiu de autoridades e não dos produtores, o que demonstra uma hierarquização da narrativa a partir dos órgãos e representantes oficiais, contrariando o que era propagado. 
Quadro 1 - Textos indicativos da participação dos produtores beneficiados

\begin{tabular}{|c|}
\hline $\begin{array}{l}\text { Meses } \\
\text { "Dessa vez não é o governo que vai dizer o que deve ser feito, mas a comunidade } \\
\text { que vai discutir o que fazer" - Secretário de Estado da Agricultura, Antônio Leonel } \\
\text { Poloni. } \\
\text { Folha de Londrina 04/03/1998 }\end{array}$ \\
\hline $\begin{array}{l}\text { Governo investiu milhóes na agricultura } \\
\text { "É a comunidade que decide de que forma aplicar os recursos, optando sempre } \\
\text { pelas áreas mais carentes e de maior potencial de mercado, com a assessoria de } \\
\text { nossos técnicos" - Humberto Malucelli Neto, gerente do Paraná } 12 \text { Meses. } \\
\text { Diário da Manhã 30/08/1999 }\end{array}$ \\
\hline $\begin{array}{l}\text { Agricultura: Rusch entrega recursos do Paraná } 12 \text { Meses } \\
\text { "O mais importante é que o Paraná } 12 \text { Meses não empurra de cima para baixo. } \\
\text { É no próprio município que as prioridades são eleitas e definido o tipo de } \\
\text { projeto em que o dinheiro será aplicado". - Deputado estadual Élio Lino Rusch } \\
\text { (PFL, partido do governador Jaime Lerner) } \\
\text { O Paraná 03/01/2002 }\end{array}$ \\
\hline
\end{tabular}

Fonte: Elaboração própria com base na análise dos jornais consultados na pesquisa.

A fala de Humberto Malucelli Neto, gerente do Paraná 12 Meses (EMATER..., 1999) destaca que as opçóes se davam por propostas de maior potencial de mercado e teriam assessoria dos técnicos envolvidos. Por si só, tal narrativa também demonstra uma condução na tomada de decisóes, imprimindo uma atuação subentendida de cima para baixo.

\section{Defesa do agronegócio e da iniciativa privada}

De uma forma aberta ou não, praticamente todos os textos analisados se mostraram favoráveis, também, a conceitos de tecnologia do agronegócio e atendimento às exigências de mercado. Do material pesquisado, 100 fazem alusão direta a tal proposta, dos quais 58 são releases do governo do Estado e/ou prefeituras, todos os demais também são decorrência de fonte oficial e com posicionamento unidimensional.

O discurso corrente nos textos apresentava o 'Paraná 12 Meses' como o projeto que iria transformar o campo, ou seja, uma 'mudança sem mudar', favorável ao agronegócio. O secretário de Estado da Agricultura e do Abastecimento, Antônio Leonel Poloni, dizia na edição do dia 03/02/1998 do 'Diário da Manhã' que o mercado era mais exigente depois da abertura econômica e por isso a ati- 
vidade do pequeno produtor deveria se adequar. Na Edição do dia 28/07/1999, a 'Folha de Londrina' publicou o artigo "Agente de transformação", de autoria do secretário, onde ele foi ainda mais incisivo, afirmando que na atualidade não havia mais espaço para paternalismos no meio rural. Dizia ainda que o governo iria trabalhar em parceria com a iniciativa privada e organizaçóes não governamentais (ONGs), personagens muito presentes nos governos neoliberais de então.

Ainda relativo à iniciativa privada, foram frequentes as notícias sobre parcerias com empresas e instituiçôes. O governo buscava apoio, por exemplo, de cooperativas, para mudar a mentalidade dos pequenos agricultores cooperados, o que significava a aceitação do modelo do agronegócio. A opção pela iniciativa privada em detrimento do Estado aparece também nas notícias sobre as vilas rurais, como de parcerias para desenvolvimento de atividades produtivas entre os moradores. Nesse sentido, surgem textos sobre acordos realizados com frigoríficos, cooperativas e empresas privadas. Em nenhum momento o pequeno produtor foi ouvido a respeito para dizer o que pensava do tema, como mostra o quadro 2 .

Quadro 2 - Matérias com posição favorável à participação da iniciativa privada

SEAB difunde Paraná 12 Meses entre cooperativas

Governo tentou inserir cooperativas no Projeto indicando cooperados com menos de 50 hectares, ajudando a elaborar projetos e dar assistência.

Diário da Manhã 13/11/98

Estímulo ao café: Lerner recebe projeto do PR 12 Meses na Copramil

Matéria diz que cooperativa desenvolveu projeto café, ou seja, participação da iniciativa privada.

Folha de Londrina 11/09/98

Café: Ribeiráo Claro inaugura laboratório do café

Trata de inauguração do laboratório instalado com recursos do Paraná 12 Meses

e participação do Sindicato Rural Patronal, SEAB e Emater.

Folha de Londrina 27/09/2001

Fonte: Elaboração própria com base na análise dos jornais consultados na pesquisa.

As práticas tradicionais de trabalho na lavoura, usadas pelos pequenos agricultores, apareciam no discurso como representantes do atraso e do antiquado, já o agronegócio neoliberal era o moderno e transformador. A iniciativa privada, segundo as fontes oficiais, traria o desenvolvimento, como destacava o secretário Antônio Leonel Poloni. O secretário também criticava outros projetos, como o 
'Paraná Rural' (anterior ao 'Paraná 12 Meses'), que considerava como exemplo errado por conta da forte presença do Estado. Dizia que dos 140 milhóes de dólares investidos na época, metade tinha sido usado para a "manutenção da máquina pública”, como declarou à 'Folha de Londrina' de 10/02/1998, na matéria 'Paraná 12 Meses já está no campo'. No texto, Poloni criticava que 50\% dos recursos do programa anterior foram usados para custeio técnico estatal e dizia que no 'Paraná 12 Meses' o dinheiro iria todo para o campo, mas com apoio da iniciativa privada. Em entrevista para a 'Folha de Londrina', o governador Jaime Lerner também fazia questão de defender a participação da iniciativa privada no 'Paraná 12 Meses': "É desta forma, dividindo responsabilidades com a iniciativa privada e com a sociedade civil organizada que, no Paraná, estamos conseguindo avançar, desenvolvendo açóes que vão contribuir para que, em pouco tempo, tenhamos no campo um novo agricultor" (LERNER..., 1999), dizia o governador.

Nesse contexto, que ganhou força na época, aumentou também a discussão sobre a necessidade de "modernizar" o serviço de extensão rural, o que, na prática, significava enxugar investimentos na Emater Paraná. A empresa incrementou a exigência junto às prefeituras no sentido de fechar convênios para realização de serviços em seus territórios. Ou seja, a prefeitura deveria ajudar a manter a estrutura da extensão rural estadual. A intensão era dividir responsabilidades e reduzir custos em uma estrutura que já se encontrava defasada. De 1980 a 2000 a empresa perdeu 400 funcionários, caindo de 1981 para 1542 o quadro de efetivos, segundo Sepulcri (2005). Em substituição, o governo de viés neoliberal terceirizava serviços, como era o caso da assistência social para atender moradores das vilas rurais. Dois releases do governo do Estado demonstram essa situação. Um deles foi 'Emater reformula e moderniza política para melhorar atendimento ao agricultor' (EMATER..., 1999). O texto tratava de convênios fechados com prefeituras que deveria pagar um valor para a realização de atividades da empresa de extensão estatal. No dia 15 de maio de 2002 o mesmo jornal publicou o release 'Assistência social volta às vilas rurais', que destacava a contratação de empresa terceirizada para fazer esse trabalho, atividade que pertencia à estrutura da Emater.

\section{Os donos da narrativa do 'Paraná 12 Meses'}

O 'Paraná 12 Meses' foi apresentado como um projeto que teria a participação direta dos beneficiários na elaboração das propostas e aplicação dos recursos. Todo trabalho, portanto, seria horizontal, no sentido de "fazer juntos" 
e não "fazer para". Na proposta apresentada ao BIRD, os produtores seriam protagonistas e náo objetos passivos de açóes.

De acordo com a Seab (2019), todas as propostas para aplicação de recursos seriam elaboradas e implementadas pelas comunidades rurais, que eram os núcleos capazes de reconhecer as necessidades locais. Assim, a participação dos beneficiários se daria pelo diálogo em todas as fases do projeto. A ideia era garantir "uma relação em que o beneficiário decide sobre seu próprio desenvolvimento" (SEAB, 2019). Dessa forma, a proposta de trabalho se apresenta de forma mais horizontal, ou mesmo "de baixo para cima".

As propostas seriam elaboradas nos municípios, pelos escritórios locais da Emater, dentro daquilo definido como prioridade pelos conselhos municipais. O 'Projeto' também contava com comissóes regionais e estadual (IPARDES, 2006). Os documentos mostram o que era proposto e como se desenvolveram as narrativas apresentadas em um momento em que o discurso neoliberal se tornou dominante no País e no Paraná, inclusive nos textos jornalísticos, ainda que proposto dentro de um sistema patrimonialista. A proposta presente era de recuperação e desenvolvimento do pequeno estabelecimento rural e torná-lo competitivo no mercado.

\section{Vozes dominantes na veiculação de notícias}

Se a comunidade era a base das açóes, seria natural que ela aparecesse no discurso de matérias, releases e artigos como protagonistas, no mínimo em posição de igualdade, e não apenas como personagens beneficiados. Mas a pesquisa demonstra que isso náo ocorreu. As vozes oficiais se apoderaram da narrativa central, como do governador Jaime Lerner, presença constante nas notícias. Mais que ele, apareceu o secretário de Estado da Agricultura e do Abastecimento, Antônio Leonel Poloni, e o secretário da Habitação, Rafael Dely (por conta das vilas rurais), personagens frequentes em repasse de recursos e inauguraçóes.

Além do governador e secretários, aparecem diretores e presidentes de outras empresas de governo envolvidas com o 'Projeto Paraná 12 Meses'. Esses atores foram as vozes políticas, na maioria das vezes, embora em alguns momentos surgissem com uma narrativa técnica. Nos planos regionais e municipais, foi comum a participação de chefes de núcleos da SEAB, Codapar, Cohapar ${ }^{11}$ e Emater.

$\overline{11}$ Companhia de Habitação do Paraná. 
As vozes oficiais dos municípios também apareceram com frequência. Prefeitos, secretários municipais e vereadores tiveram como narrativa central o agradecimento e elogios ao governo do Estado. Em suas palavras, o 'Paraná 12 Meses' era apontado como o maior projeto já desenvolvido no Paraná. Técnicos municipais que trabalhavam em conjunto com o Estado no atendimento aos beneficiários, também estavam no discurso.

Deputados estaduais governistas eram constantes, principalmente quando se tratava do repasse de recursos. Nesses casos, eles aproveitavam politicamente o espaço para se colocarem como portadores dos cheques nas solenidades em que os valores eram entregues. Percebe-se que os jornais davam espaço para determinados nomes, entre os deputados, que foram recorrentes ao longo dos quatro anos como responsáveis pelos repasses e sempre com direito a longas falas em primeira pessoa. Termos como "o maior investimento já feito" e "revolução no campo", foram publicados constantemente.

Matérias e releases também destacaram representantes do BIRD, quando da avaliação do 'Paraná 12 Meses', e da iniciativa privada, com atores das agroindústrias e cooperativas falando do projeto. Os produtores beneficiados apareceram sempre como personagens atendidos.

Não é objetivo deste trabalho quantificar o conteúdo das falas, mas a tabela ' 3 ' ilustra a participação dos atores. A variedade de vozes é relativamente alta, com representantes de governos estadual e municipais, produtores e iniciativa privada.

Tabela 3 - Principais vozes presentes nos textos publicados nos jornais

\begin{tabular}{l|c}
\hline ATORES DONOS DO DISCURSO & VEZES \\
\hline Autoridades do governo, incluindo governador e secretários & 103 \\
\hline Técnicos do Estado e chefes regionais & 57 \\
\hline Prefeitos, vereadores, secretários e técnicos municipais & 53 \\
\hline Deputados e autoridades políticas & 49 \\
\hline Pequenos produtores e vileiros beneficiários & 35 \\
\hline Coordenadores do projeto & 26 \\
\hline Iniciativa privada e representantes da grande propriedade & 9 \\
\hline
\end{tabular}

Fonte: Elaboração própria com base na análise dos jornais consultados na pesquisa.

Secretários de Estado e o governador Jaime Lerner foram as principais vozes na apresentação do 'Projeto Paraná 12 Meses', principalmente na defesa 
do aspecto neoliberal. O discurso corrente entre secretários e o governador era favorável ao agronegócio e da necessidade de estar preparado para ser competitivo no mercado, que chamam de globalizado, após a abertura econômica do governo Fernando Henrique Cardoso no plano federal. Prefeitos e demais políticos aparecem nos textos como distribuidores dos recursos e para elogiar o 'Projeto'. Nota-se que em termos quantitativos há pouca presença da iniciativa privada, porém o papel deles é citado na maioria dos textos pelas personagens oficiais e/ou políticas.

Quadro 3 - Discurso político favorável à 'modernização' do Paraná 12 Meses

Governo Lerner garante terra para 16 mil famílias

Balanço do projeto 'Vilas Rurais' e explicação de como funciona.

Diário da manhã 16/06/02

Paraná 12 Meses melhora as condiçóes de vida no campo

Texto é uma descrição do projeto, insistindo no protagonismo do produtor. Folha de Londrina 30/06/1999

Dely e Burin inauguram Vila Rural

Inauguração de vila rural em Palotina. Prefeito e presidente da Câmara elogiam o projeto e dizem que é a reforma agrária que todos querem: "Sem violência, sem invasão e com justiça social”.

O Paraná 30/09/1999

Plauto leva Paraná 12 Meses a Ipiranga

Entrega de recursos do projeto. Falam do empenho do governo do Estado e do deputado Plauto Miró.

Diário da Manhã 27/05/2002

\section{Oeste ganha mais três Vilas Rurais}

Texto enaltece o projeto na voz de prefeitos e do secretário de Habitação, Rafael Dely.

O Paraná 13/06/1999

Fonte: Elaboração própria com base na análise dos jornais consultados na pesquisa.

A narrativa do 'Paraná 12 Meses' abriu espaço para a avaliação de representantes dos grandes produtores rurais (empresários rurais) e de setores do agronegócio. O objetivo parece ter sido de buscar uma aprovação do empresário rural para os investimentos feitos ao pequeno produtor de maneira a não alterar o modelo fundiário estadual. As vozes presentes foram favoráveis e elogiosas à proposta de aproximaçáo dos projetos à lógica do mercado agroindustrial. Em um artigo publicado em 23 de junho de 2001, no 'Diário da Manhã', um latifundiário dizia: "O bóia fria coopera com o grande produtor, sendo, às vezes, 
até indispensável”. Quanto à equipe técnica, teve o papel de tratar das questóes operacionais e produtivas.

\section{O papel do beneficiado na narrativa}

A tabela 3 mostra uma presença significativa de pequenos produtores na narrativa. Todos eles são beneficiários do 'Paraná 12 Meses', principalmente moradores das vilas rurais. Se fosse observado apenas pelo aspecto quantitativo, a conclusão seria de que há sim uma participação efetiva de tal público e uma horizontalidade na produção de sentido do 'Projeto'. Porém, o levantamento quantitativo é insuficiente para se tirar essa conclusão. A análise do discurso dos textos mostrou que não se trata de uma fala participativa, mas de legitimação da narrativa oficial, construída por jornalistas e assessores de imprensa, a partir de agradecimentos e elogios aos investimentos. O pequeno produtor, tratado dentro da lógica da agricultura familiar do agronegócio, surge como "personagem" objeto dos investimentos. Os textos comparam o "antes e o depois" na vida dos beneficiados.

Quadro 4 - Discurso de beneficiários do

'Projeto Paraná 12 Meses' como personagens

\begin{tabular}{|c|}
\hline $\begin{array}{l}\text { "Estou realizado. Trabalhei durante anos como arrendatário e todo lucro, no } \\
\text { final das contas, ia para o bolso do dono da terra. Aqui eu sou o dono e a nossa } \\
\text { vida nunca foi táo boa". - Joel de Almeida, morador da Vila Rural Colina da } \\
\text { Esperança, de Lindoeste. } \\
\text { Diário da Manhã 14/12/2000 }\end{array}$ \\
\hline $\begin{array}{l}\text { Dely e Burin Inauguram vila rural } \\
\text { "Essa casinha e esse pedaço de chão era tudo que eu pedia na vida". - Dionísio } \\
\text { Bento de Souza, morador da Vila Rural Terra da Gente, de Palotina. } \\
\text { O Paraná 28/09/2000 }\end{array}$ \\
\hline $\begin{array}{l}\text { ira safra } \\
\text { urar quase R\$ } 600 \text { nas minhas mãos. } \\
\text { o, num lote que náo é dos outros. É } \\
\text { Rural Luz da Terra, de Braganey. }\end{array}$ \\
\hline
\end{tabular}

Fonte: Elaboração própria com base na análise dos jornais consultados na pesquisa.

Exemplos como das matérias do quadro 4 foram frequentes em publicaçóes onde aparecem os pequenos produtores. A análise demonstrou que o 
'Paraná 12 Meses' teve grande variedade de vozes em matérias, releases e artigos, mas sempre com um discurso único, em consonância com a proposta. Ao contrário do conceito jornalístico de objetividade e imparcialidade, em nenhum texto há oposição ou questionamentos ao 'Projeto'.

\section{Apoderação discursiva do projeto}

Com relação aos atores centrais, as autoridades falavam em nome dos produtores assistidos, sempre definindo o que era bom ou ruim para eles. O 'Paraná 12 Meses' aparecia como um estímulo para produzir mais e melhor, inserido nas propostas do agronegócio, considerado como via única a ser seguida pela pequena produção, uma via unidimensional marcusiana. Os políticos, em especial prefeitos e deputados, apareciam como responsáveis pela conquista dos recursos junto ao governo do Estado ou, pelo menos, como os grandes parceiros do governo. Equipes técnicas foram ouvidas para dar explicaçóes sobre projetos e os beneficiários como personagens legitimadoras das qualidades dos investimentos.

Além disso, a narrativa construída pelas assessorias de imprensa e jornais mostra um "sequestro" do discurso de construção do projeto pelo meio político. Como pode ser visto no quadro 5, tais atores apareceram muitas vezes se apropriando da elaboração a partir da distribuição de recursos, o que dava ao receptor a ideia de que era uma conquista desses personagens e não projetos elaborados em conjunto pela comunidade.

Quadro 5 - Apropriação do projeto por vozes políticas no discurso jornalístico

Zuk afirma que Paraná 12 Meses vem para recuperar o setor da agricultura Luiz Carlos Zuk, deputado estadual governista.

(Diário da Manhã -05/02/1998)

Plauto anuncia R\$ 2,4 milhóes para a agricultura - Plauto Miró Guimarães Filho, deputado estadual governista.

(Diário da Manhã - 02/04/2002)

Henrichs repassa recursos para vileiros - José Carlos Henrichs, prefeito de Boa Vista de Aparecida.

(O Paraná - 18/02/2001)

Elio e Adelar Entregam recursos do PR 12 Meses - Élio Rusch, deputado estadual governista e Adelar Arrosi, prefeito de Ibema.

(O Paraná - 13/02/1999)

Fonte: Elaboração própria com base na análise dos jornais consultados na pesquisa. 
Numa época que a internet ainda era insipiente e a redes sociais não existiam, se observa que vozes oficiais agiram necessariamente em conjunto com os veículos de mídia impressos na defesa do modelo proposto e aplicado no 'Paraná 12 Meses'. A partir da concordância com um pensamento único, o discurso tornou-se alinhado e oferecido aos leitores. A proposta do projeto, ainda que sem citar ou sem ser proposital, seguiu os conceitos defendidos por Paulo Freire (2001), de horizontalidade e participação efetiva do produtor rural como protagonista. Mas a narrativa presente na mídia mostra que isso não ocorreu na prática, ao contrário, percebe-se um protagonismo intenso das fontes oficiais e uma presença do beneficiário apenas como objeto receptor.

\section{O pensamento único consolidado por fontes oficiais}

A partir da análise de discurso, observa-se que um projeto dominante pode ser tratado de forma unidimensional, como verdade única. Quem seria o sujeito dessa ação, ou seja, o pequeno produtor rural, torna-se objeto reificado (LUKÁCS, 2003), ou coisificado (FREIRE, 2001). Ao se referir à 'unidimensionalidade', Herbert Marcuse (1973) também analisa a discursividade. Para o autor, o processo de dominação passa por uma linguagem unificada, contrária a qualquer distinção.

A síntese proposicional liga a ação (ou estado) ao sujeito, de tal maneira que este é designado como o ator (ou portador) e é assim distinguido do estado ou função em que aconteça estar (...) E se uma sentença dá uma definição de seu sujeito, não dissolve o sujeito em seus estados ou funçôes, mas o define como estando neste estado ou exercendo esta função. (MARCUSE, 1973, p 102).

Marcuse (1973) afirma que as "abreviaturas linguísticas” promovem conteúdos sociais e suprimem outros. A imposição unidimensional demonstra que quem tem a supremacia, pelo voto, econômico e/ou como emissor, impóe um discurso e suprime outro, contrário ao seu. No caso do 'Paraná 12 Meses', isso pode ser visto claramente, já que as vozes oficiais dominaram a emissão da mensagem e a narrativa oficial predominou mesmo na fala dos beneficiários, usados como legitimadores do discurso governamental.

Se a análise de discurso deve se valer da palavra em movimento para ver qual é a significação do texto (ORLANDI, 2007), toda estrutura de comunicação mostrou uma afirmação de sentidos favorável à inserção do pequeno produ- 
tor ao agronegócio. A justificativa do trabalho dava conta de analisar exatamente a proposta que pode estar por trás da política pública divulgada como horizontal. Na prática, o que pode ocorrer é a dominação e legitimação de determinada ordem a partir da produção de discursos das autoridades (CHARAUDEAU, 2016). Nesse caso, como se observou na pesquisa, as vozes oficiais foram predominantes na apresentação do 'Paraná 12 Meses'.

\section{Considerações finais}

A análise mostrou que o 'Paraná 12 Meses' teve grande variedade de vozes publicadas nos jornais, mas geralmente com a mesma narrativa, em concordância com o projeto. Os atores presentes na construção discursiva, portanto, foram os representantes de governo e da estrutura do 'Projeto', como técnicos e conselheiros, além de políticos governistas, incluindo deputados e prefeitos alinhados. Até mesmo os representantes do agronegócio, como diretores de cooperativas e grandes produtores tiveram espaço.

Os textos analisados demonstraram uma narrativa alinhada com as propostas neoliberais, como defesa do estado mínimo e incremento da iniciativa privada, globalização, exigências de mercado no agronegócio e terceirização dos serviços. Tais resultados podem ser, portanto, uma afirmativa da ocorrência da unidimensionalidade industrial (MARCUSE, 1969) também no meio rural. As vozes oficiais predominaram durante todo desenvolvimento do projeto. Isso é observado nos textos e subtextos, a partir de quem fala e da maneira como fala (CHARAUDEAU, 2010). Tal posição contou, também, com postura favorável dos veículos de comunicação, que atuaram em consonância com o governo, confirmando a afirmação de Charaudeau (2016), que diz que há uma ação conjunta entre governo e mídia na divulgação de assuntos de interesse governamental.

A conclusão é que a horizontalidade proposta pelo projeto não se confirmou nos discursos, o que se viu foi a verticalização narrativa. As vozes oficiais trataram os pequenos produtores como público atendido, impondo um ponto de vista sobre o que e como produzir. Quando ouvidos, esses agricultores sempre apareceram como personagens alvos dos projetos, destacando a importância do 'Paraná 12 Meses'. Se a análise fosse quantitativa, demonstraria uma presença razoavelmente constante dos beneficiários, mas a observação do discurso mostrou que o papel que coube a eles foi de legitimação da proposta oficial, com elogios e agradecimentos. Foi, então, o personagem alvo dos investimentos, que precisava de políticas compensatórias para evoluir dentro da unidimensionalidade do agronegócio. 
Se houvesse igualdade, a fala dos beneficiários teria de ser mais técnica e demonstrar que foi uma decisão deles, também, a adesão às propostas desenvolvidas, o que não ocorreu. $\mathrm{O}$ protagonismo do discurso ficou a cargo do governo e políticos, colocados em posição superior ao pequeno produtor. Como protagonistas, defenderam uma proposta de inserção dos pequenos estabelecimentos à lógica do agronegócio industrial, como consumidores de insumos e fornecedores de matéria prima. O governador Jaime Lerner, os secretários da Agricultura e do Abastecimento, Antônio Leonel Poloni e da Habitação, Rafael Dely, orientaram o discurso no sentido de apresentar o agronegócio e o neoliberalismo como únicos caminhos para a existência no meio rural, inclusive para o pequeno agricultor.

Observa-se, portanto, que uma proposta de horizontalidade, para ser comprovada, precisa se expressar na discursividade. Além disso, em um processo horizontal, haveria uma diversidade de ideias. $\mathrm{O}$ discurso presente na divulgação de um projeto grandioso, como o 'Paraná 12 Meses', não confirmou paridade entre os atores e impôs um modelo unidimensional e vertical de desenvolvimento.

Percebe-se similaridade entre a unidimensionalidade urbana/industrial e o que se observou no discurso para o meio rural. Em temas macroeconômicos, há um destaque muito maior ao que pensa e quer o mercado, seja em crises ou em investimentos. A análise do 'Paraná 12 Meses' apresentou as mesmas características, com o mercado em primeiro plano e o pequeno produtor rural ocupando um papel secundário, como se o estabelecimento rural fosse apenas uma extensão da fábrica.

\section{Referências}

ALTAFIN, I. Reflexóes sobre o conceito de agricultura familiar. Brasília, 2005. Disponível em: http://www.enfoc.org.br/system/arquivos/documentos/70/f1282 reflexoes-sobre-o-conceito-de-agricultura-familiar---iara-altafin---2007.pdf. Acesso em: 07 jan. 2021.

BALSAN, R. Impactos decorrentes da modernização da agricultura brasileira. Campo - Território: revista de geografia agrária-UFU, Uberlândia, v.1, n.2, p.123-151, ago. 2006.

BANCO MUNDIAL. Relatório sobre o Desenvolvimento Mundial. Washington, DC, 1997.

BARROS FILHO, C. de. Ética na comunicaçáo. 3. ed. São Paulo: Summus, 2003. 
CAMILOTTO, C. A. G.; CRHISPIM, R. G.; LOPES FILHO, B. B. L. Indivíduos e organizaçóes na sociedade civil interface entre a esfera política e o capital social. Comunicação \& Mercado, Dourados, v. 4, n. 11, p. 70-82, 2015.

CARVALHO, G. Diretrizes para análise de discurso em jornalismo. Revista Uninter de Comunicação, Curitiba, n.1, p. 5-27, jun./dez. 2013.

CHARAUDEAU, P. A conquista da opiniáo pública: como o discurso manipula as escolhas políticas. São Paulo: Contexto, 2016.

CHARAUDEAU, P. Discurso das mídias. São Paulo: Contexto, 2010.

CONSELHO DE DESENVOLVIMENTO DO EXTREMO SUL [CODESUL]. O papel social do pequeno estabelecimento rural no Paraná. Curitiba, 1978.

CUNHA, L. A. G. Questão agrária e região no Paraná. In: ROSAS, C. A. R. F. (org.). Perspectivas da geografia agrária no Paraná: abordagens e enfoques metodológicos. Ponta Grossa: Estúdio Texto, 2015. p. 51-59.

DUARTE, J. Comunicação pública: Estado, mercado, sociedade e interesse público. 3. ed. São Paulo: Atlas, 2012.

EMATER reformula e moderniza política para melhorar atendimento ao agricultor. Diário da Manhá, Ponta Grossa, p.10, 27 jan. 1999.

FAJARDO, S. Aspectos da ocupação, da formação da estrutura produtiva e das transformaçóes na paisagem rural no território paranaense. Caminhos de Geografia, Uberlândia, v.7, n. 20, p. 89-101, fev. 2007.

FANINI, A. M, R.; SOUZA, M.; PEREIRA, D. S. Uma análise discursiva sobre parcialidade, pluralidade de vozes e princípio do contraditório em uma agência estadual de notícias. Discursos Fotográficos, Londrina, v.11, n.18, p.143-170, jan./jun. 2015.

FERNANDES, B. M. Espaços agrários de inclusão e exclusão social: novas configuraçôes do campo brasileiro. Agrária, São Paulo, n. 1, p. 16-36, 2004.

FERREIRA, A. D. Movimentos sociais rurais no Paraná: 1978-1982. In: BONIM, A.A. et al. Movimentos sociais no campo. Curitiba: Ed. da Universidade Federal do Paraná, 1987.p. 9-50.

FREIRE, P. Extensão ou comunicaçáo? 11. ed. Rio de Janeiro: Paz e Terra, 2001.

INSTITUTO PARANAENSE DE DESENVOLVIMENTO ECONÔMICO E SOCIAL [IPARDES]. Avaliaçáo institucional do Projeto Paraná 12 Meses. Curitiba, 2006. 
LERNER garante apoio ao campo. Folha de Londrina, Londrina, p.6, 28 jul. 1999. LUKÁCS, G. História e consciência de classe: estudos sobre a dialética marxista. São Paulo: Martins Fontes, 2003.

MACHADO, B. P. Contribuição ao estudo da história agrária do Paraná: formação da estrutura agrária tradicional dos Campos Gerais. In: ANPUH, 2., Curitiba. Anais [...], Curitiba, 1962.

MAFEI, M. Assessoria de imprensa: como se relacionar com a mídia. São Paulo: Contexto, 2012.

MARCUSE, H. Tecnologia, guerra e fascismo. São Paulo: Ed. da Unesp, 1998.

MARCUSE, H. Eros e civilizaçáo: uma interpretação filosófica do pensamento de Freud. 6. ed. Rio de Janeiro: Zahar, 1975.

MARCUSE, H. A ideologia da sociedade industrial: o homem unidimensional. 4. ed. Rio de Janeiro: Zahar, 1973.

MARCUSE, H. An essay on liberation. Boston: Beacon Press, 1969. Disponível em: https://www.marxists.org/reference/archive/marcuse/works/1969/essay-liberation. htm. Acesso em: 12 fev. 2021.

MARTINS, J. de S. O cativeiro da terra. São Paulo: Hucitec, 1986.

ORLANDI, E. P. Discurso e texto: formulação e circulação dos sentidos. Campinas, SP: Pontes, 2008.

ORLANDI, E. P. Análise de discurso: princípios e procedimentos. Campinas, SP: Pontes, 2007.

PADIZ, P. C. Formaçáo de uma economia periférica: o caso do Paraná. 2. ed. Curitiba: Ipardes, 2006.

PARANÁ. Projeto Paraná 12 Meses Síntese. Curitiba, 1997.

PARANÁ. Secretaria de Estado da Agricultura e do Abastecimento - SEAB. Unidade de Gerenciamento do Projeto Paraná 12 Meses. Projeto Paraná 12 Meses: Manual de Campos. Curitiba, 1996.

PÊCHEUX, M. O discurso: estrutura ou acontecimento. 4. ed. Campinas, SP: Pontes, 2006.

PEREIRA, J. M. M. A reforma agrária assistida pelo mercado do Banco Mundial na África do Sul e no Brasil (1994-2002). Estudos Ibero-Americanos, Porto Alegre, v.43, n.1, p. 218-235, 2017 a. 
PEREIRA, J. M. M. Metamorfoses da política de ajuste estrutural do Banco Mundial (1980-2014). Revista Sociologias, Porto Alegre, ano 19, n.44, p. 390-422, jan/abr. $2017 b$.

ROLIM, C. F. C. O Paraná urbano e o Paraná do agrobusiness: as dificuldades para a formulação de um projeto político. Revista Paranaense de Desenvolvimento, Curitiba, n. 86, p.49-99, set/dez. 1995.

SECRETARIA DE ESTADO DA AGRICULTURA E DO ABASTECIMENTO [SEAB]. Projeto Paraná 12 Meses. Disponível em: http://www.simep.seab.pr.gov.br/ pr12meses/index.html. Acesso em: 20 mar. 2019.

SEPULCRI, O. Estratégias e trajetórias institucionais da Empresa de Assistência Técnica e Extensão Rural do Paraná (Emater-PR). 2005. 145 f. Dissertação (Mestrado em Desenvolvimento Econômico) - Centro de Pesquisas Econômicas, Universidade Federal do Paraná, Curitiba, 2005.

SERRA, E. O novo modelo agrícola e a proletarização do trabalhador rural no norte do Paraná. In: ROSAS, C. A. R. F. (org.). Perspectivas da geografia agrária no Paraná: abordagens e enfoques metodológicos. Ponta Grossa: Estúdio Texto, 2015. p. 25-38.

SERRA, E. Os primeiros processos de ocupaçáo de terra e a organização pioneira do espaço agrário do Paraná. Boletim de Geografia, Maringá, ano 10, n. 1, p. 61-89, 1992.

SILVA, J. G. da. A estrutura agrária do Estado do Paraná. Revista Paranaense de Desenvolvimento, Curitiba, n.87, p. 175-195, 1996.

SOUZA, H. J. de. Análise de Conjuntura. 27. ed. Petrópolis: Vozes, 1984.

TRAQUINA, N. Teorias do Jornalismo: Porque as notícias são como são. 3. ed. Florianópolis: Insular, 2012.

WILKSON, J. Distintos enfoques e debates sobre a produção familiar no meio rural. Agroecologia e desenvolvimento rural sustentável, Porto Alegre, v.1, n.3, p. 20-30, jul/set. 2000.

Recebido em: 12 de setembro de 2020

Aprovado em: 22 de outubro de 2020 